91 Novita Taya Sara, Rusnaini, Winarno: strategi guru dalam pembelajaran ...

\title{
STRATEGI GURU DALAM PEMBELAJARAN BERPIKIR KRITIS PESERTA DIDIK MELALUI UNIT KEGIATAN BELAJAR MANDIRI MATA PELAJARAN PPKn (Studi di SMA Negeri 3 Surakarta)
}

\author{
Oleh : \\ Novita Taya Sara, Rusnaini, Winarno \\ Program Studi PPKn FKIP Universitas Sebelas Maret Surakarta \\ e-mail: novitatayasara301@gmail.com
}

\begin{abstract}
The research aims to find out: 1) The strategy of teachers in student's critical thinking learning using self learning activity in Pancasila and Citizenship Education in SMA Negeri 3 Surakarta; 2) Teacher's supporting factors and inhibitory factor in critical thinking learning using self learning activity in Pancasila and Citizenship Education in SMA Negeri 3 Surakarta.

They study uses a qualitative approach, a type of qualitative descriptive research. Data sources are obtained from the informant, place and document. Sampling techniques using purposive sampling. Data collection techniques using interviews, observations, and document analysis. Data validity using trianggulation data and Trianggulation method. Analyze data using interactive analysis models.

Result of the research: 1) The strategy of teachers in student's critical thinking learning using self learning activities in Pancasila education subjects and citizenship in Pancasila and Citizenship Education in SMA Negeri 3 Surakarta: a) Teacher need to learn and understand about the components development and characteristics of self learning activities ; b) The teacher makes a learning activity by displaying questions of Higher Order Thinking Skills (HOTS); c) The teacher makes the look of self learning activity; and d) The teacher designed the planning, implementation, and evaluation activities. 2) The teacher's supporting factor in student's critical thinking learning using self learning in Pancasila Education and Citizenship course includes: a) schools facilities; b) The positive response from the students with the self learning activity; c) Learning activities in the self learning activities lead to the growing Higher Order Thinking Skills (HOTS) that support critical thinking skills; d) Self learning activities as a selflearning strategy that helps learners achieve learning submission. The inhibitory factor includes internal factors: a) The feeling of fear of self-learners; b) lack of ability to communicate students; and c) lack of motivation in the students in the interest of the study of Pancasila and the citizenship. External factors include: a) The responses of nearby friends who often laugh at other learners when they wrong answer; b) Limited time allocation; c) Learners who have completed self learning activity of Pancasila and Citizenship Education must wait for other learners to get new material taught by the teacher and; d) Find it difficult to print the modul for the self learning activity of Pancasila and Citizenship Education because of the limited fund of the school.
\end{abstract}

Keywords: Strategies, Critical Thinking, Self Learning Activity, Pancasila Education and Citizenship 


\section{PENDAHULUAN}

Pendidikan berperan sebagai cerminan dalam kehidupan suatu bangsa, jika kualitas pendidikan suatu bangsa baik maka kualitas sumber daya manusia yang dimiliki suatu bangsa akan baik pula. Upaya peningkatan kualitas sumber daya manusia merupakan perwujudan dari Sistem Pendidikan Nasional tercantum dalam Pasal 3 UndangUndang No.20 Tahun 2003.

Pendidikan nasional memiliki fungsi untuk mengembangkan kemampuan serta membentuk watak dan peradaban bangsa, memiliki tujuan untuk berkembangnya potensi peserta didik supaya menjadi manusia yang beriman dan bertaqwa kepada Tuhan Yang Maha Esa, Berakhlak mulia, sehat, berilmu, cakap,kreatif,mandiri, serta menjadi warga negara yang demokratis dan bertanggung jawab.

Berbagai keterampilan dituntut untuk dikuasai peserta didik di kehidupan di abad ke-21. Unesco dalam E. Mulyasa (2005: 5) mengemukakan, "Dua prinsip pendidikan yang relevan dengan Pancasila: pertama; pendidikan harus diletakkan dalam empat pilar, yaitu belajar mengetahui (learning to know), belajar melakukan (learning to do), belajar menjadi diri sendiri (learning to be); kedua, belajar seumur hidup (learning to live together).". Empat prinsip tersebut masing-masing mengandung keterampilan khusus yang perlu diberdayakan dalam kegiatan belajar, seperti keterampilan berpikir kritis, pemecahan masalah, metakognisi, keterampilan berkomunikasi, berkolaborasi, inovasi dan berbagai keterampilan lainnya. Secara singkat, pembelajaran abad ke-21 memiliki prinsip pokok bahwa pembelajaran harus berpusat pada siswa.

Pendidikan Kewarganegaraan memiliki peran yang penting dalam membentuk watak dan karakter warga negara agar mampu bersaing di era global. Pendidikan Kewarganegaraan menjadi pengembang utama dalam meningkatkan sistem pendidikan nasional agar siap berpartisipasi menjadi warga negara global. Rusnaini (2018: 4) mengemukakan "Pada akhir abad ke 20 konsep citizenship education or education for citizenship yang diartikan sebagai the contribution of education to the development of those characteristics of being a citizen atau kontribusi pendidikan untuk membangun jatidiri kewarganegaraan telah berkembang mendunia".

Mulai tahun pelajaran 2013/2014 Kementrian Pendidikan dan Kebudayaan telah memberlakukan kurikulum 2013. Salah satu langkah dalam penyusunan kurikulum 2013 adalah penataan ulang Pendidikan Kewarganegaraan (PKn) menjadi Pendidikan Pancasila dan Kewarganegaraan yang untuk selanjutnya disebut (PPKn).Sehubungan dengan adanya perubahan substansi tersebut penelitian ini memfokuskan pada Pendidikan Pancasila dan Kewarganegaraan kurikulum 2013.

Mata pelajaran Pendidikan Pancasila dan Kewarganegaraan tidak hanya sebatas dilakukan pemahaman konsep-konsep saja, tetapi juga menuntut penguasaan keterampilan-keterampilan tertentu 
seperti berbicara atau mengeluarkan pendapat secara baik dan benar, berpartisipasi aktif di dalam kelas dan berpikir kritis. Winarno (2013: 98) menyebutkan bahwa "Berpikir kritis termasuk dalam keterampilan kewarganegaraan (civic skill), yaitu pada bagian keterampilan berpikir kritis atau keterampilan intelektual (intellectual civic skill). Misalnya keterampilan mengidentifikasi, keterampilan berargumen, keterampilan mengambil posisi, dan lain-lain". Oleh karena itu, dalam pembentukan keterampilan kewarganegaraan diperlukan strategi agar peserta didik memiliki keterampilan kewarganegaraan tersebut.

Penelitian dari Tri Partini (2015: 4) menunjukkan bahwa pembelajaran PPKn belum sepenuhnya mampu menjalankan tujuan dan fungsinya dengan baik , ditemukan beberapa permasalahan yang menunjukkan rendahnya kualitas proses pembelajaran diantarannya rendahnya kemampuan berpikir kritis peserta didik pada mata pelajaran PPKn. Hal ini ditandai dengan indikator sebagai berikut: (1) banyak peserta didik tidak mengenali masalah; (2) sebagian besar peserta didik tidak berusaha mencari informasi dari berbagai sumber yang tersedia; (3) Peserta didik tidak dapat menarik kesimpulan dari materi yang dipelajari. Penelitian dari Nurul Istikomah (2018: 7) juga semakin memperkuat bahwa dalam pembelajaran PPKn siswa hanya merekam apa yang disampaikan guru di kelas.

Kemampuan berpikir kritis merupakan salah satu kemampuan yang penting untuk dikembangkan di seluruh jenjang pendidikan. Hal ini karena kurikulum yang digunakan di Negara Kesatuan Republik Indonesia saat ini adalah Kurikulum 2013 yang mana didalamnya menuntut peserta didik untuk memiliki kemampuan berpikir tingkat tinggi (Higer Order Thinking Skills / HOTS). SMA Negeri 3 Surakarta merupakan sekolah unggulan dimana guru PPKn menginginkan peserta didik dapat mencapai kemampuan berpikir tingkat tinggi ( Higer Order Thinking Skills / HOTS ) ada beberapa kelas di SMA Negeri 3 Surakarta yang menerapkan Sistem Kredit Semester ( SKS ) dimana dalam sistem SKS itu memadatkan jam pelajaran dalam prosesnya, materi per kompetensi dasar nya diselesaikan dalam 1-2 pertemuan , Guru PPKn mempercepat proses pembelajaran agar peserta didik dapat mencapai target kelulusan dalam kurun waktu 2 tahun. Dengan kondisi yang demikian ini menyebabkan peserta didik kesulitan dalam mengembangkan kemampuan pengetahuannya , utamanya pengetahuan dalam berpikir kritis. Strategi pembelajaran berpikir kritis peserta didik diterapkan oleh guru PPKn di SMA Negeri 3 Surakarta salah satunya melalui Unit Kegiatan Belajar Mandiri. mata pelajaran Pendidikan Pancasila dan Kewarganegaraan , Unit Kegiatan Belajar Mandiri yang untuk selanjutnya disebut dengan UKBM merupakan satuan pelajaran yang kecil yang disusun secara berurutan dari yang mudah sampai ke yang sukar ( Kemendikbud, 2017: 3 ).

Berdasarkan latar belakang di atas pada akhirnya ada usaha-usaha 
dari guru PPKn di SMA Negeri 3 Surakarta dengan memiliki strategi dalam pembelajaran berpikir kritis peserta didik, salah satunya melalui UKBM (Unit Kegiatan Belajar Mandiri) mata pelajaran Pendidikan Pancasila dan Kewarganegaraan . Kebijakan UKBM mulai diterapkan di SMA Negeri 3 Surakarta pada tahun 2018. Berdasarkan hasil wawancara dengan guru PPKn di SMA Negeri 3 Surakarta, peserta didik di SMA Negeri 3 Surakarta kemampuan berpikir kritisnya masih kurang dalam mata pelajaran PPKn sebelum diterapkannya UKBM mata pelajaran PPKn karena mereka cenderung menerima materi yang disampaikan guru. Jadi dapat dikatakan bahwa UKBM (Unit Kegiatan Belajar Mandiri) merupakan stimulus belajar yang memungkinkan tumbuhnya kemandirian dan pengalaman peserta didik untuk terlibat aktif dalam penguasaan kompetensi secara utuh, berpikir tingkat tinggi (Higer Order Thinking Skill / HOTS dan berpikir kritis. Oleh karena itu peneliti merasa tertarik untuk melakukan penelitian mengenai sejauh mana dampak Unit Kegiatan Belajar Mandiri mata pelajaran Pendidikan Pancasila dan Kewarganegaraan terhadap peningkatan kemampuan berpikir kritis peserta didik sebagai salah satu strategi yang dilakukan oleh guru PPKn di SMA Negeri 3 Surakarta.

Tujuan dalam penelitian ini adalah untuk: 1) mengetahui strategi guru dalam pembelajaran berpikir kritis peserta didik melalui Unit Kegiatan Belajar Mandiri mata pelajaran Pendidikan Pancasila dan Kewarganegaraan di SMA Negeri 3 Surakarta. 2) mengetahui faktor pendukung dan faktor penghambat guru dalam pembelajaran berpikir kritis peserta didik melalui Unit Kegiatan Belajar Mandiri mata pelajaran Pendidikan Pancasila dan Kewarganegaraan di SMA Negeri 3 Surakarta. Hasil penelitian ini diharapkan dapat memberikan manfaat untuk beberapa kalangan baik manfaat secara teoritis maupun secara praktis. Secara teoritis penelitian ini diharapkan dapat membantu guru memberikan informasi tentang strategi guru dalam pembelajaran berpikir kritis peserta didik melalui Unit Kegiatan Belajar Mandiri mata pelajaran Pendidikan Pancasila dan Kewarganegaraan. Sedangkan manfaat praktis dalam penelitian ini adalah untuk pendidik khususnya SMA untuk mata pelajaran Pendidikan Pancasila dan Kewarganegaraan bahwa dengan strategi yang digunakan diharapkan guru mampu menerapkan pembelajaran berpikir kritis peserta didik melalui Unit Kegiatan Belajar Mandiri (UKBM) mata pelajaran PPKn.

\section{METODE PENELITIAN}

Penelitian ini dilaksanakan di SMA Negeri 3 Surakarta. Penelitian ini menggunakan metode kualitatif, hal tersebut karena hasil penelitian memaparkan obyek yang diteliti (orang, lembaga atau yang lainnya) yang berdasarkan fakta. Sementara itu pendekatan yang digunakan adalah deskriptif kualitatif, peneliti berusaha menyajikan data deskriptif berupa informasi atau tanggapan dari informan, observasi lapangan dan studi dokumen yang berhubungan dengan objek. Penelitian ini 
memfokuskan pada strategi guru dalam pembelajaran berpikir kritis peserta didik melalui Unit Kegiatan Belajar Mandiri mata pelajaran Pendidikan Pancasila dan Kewarganegaraan serta faktor pendukung dan faktor penghambat guru dalam pembelajaran berpikir kritis peserta didik melalui Unit Kegiatan Belajar Mandiri mata pelajaran Pendidikan Pancasila dan Kewarganegaraan Sumber data dalam penelitian ini diperoleh dari informan, tempat, serta dokumen terkait.

Teknik pengambilan sampel yang digunakan adalah purposive sampling. Menurut Sugiyono (2010:300) menyatakan bahwa "Purposive Sampling yaitu teknik penentuan sampel dengan pertimbangan tertentu". Jadi peneliti mengambil sampel Guru Pendidikan Pancasila dan Kewarganegaraan dan beberapa peserta didik dengan pertimbangan bahwa guru dan peserta didik tersebut dapat memberikan data atau informasi yang lengkap.

Pengumpulan data dalam penelitian ini dilakukan dengan beberapa teknik yaitu dengan wawancara, observasi, dan studi dokumen. Wawancara dalam penelitian ini dilakukan terhadap guru mata pelajaran Pendidikan Pancasila dan Kewarganegaraan di SMA Negeri 3 Surakarta serta peserta didik SMA Negeri 3 Surakarta. Selain itu observasi dilakukan dengan mengamati kegiatan belajar mengajar di dalam kelas. Dokumen yang dianalisis dalam penelitian ini adalah Unit Kegiatan Belajar Mandiri mata pelajaran Pendidikan Pancasila dan
Kewarganegaraan yang dibuat oleh guru.

Teknik uji validitas data yang digunakan dalam penelitian ini adalah trianggulasi data dan trianggulasi metode. Dalam hal ini, data yang sama atau sejenis akan lebih valid kebenarannya bila digali dari beberapa sumber yang berbeda yaitu guru mata pelajaran PPKn dan beberapa perwakilan peserta didik di SMA Negeri 3 Surakarta. Kemudian memadukan hasil observasi dan analisis beberapa sumber yang berbeda. Sedangkan untuk menguji validitas trianggulasi metode dalam penelitian ini diperoleh dengan menggunakan metode yang berbeda, yaitu dengan metode wawancara dengan guru mata pelajaran PPKn dan beberapa perwakilan peserta didik di SMA Negeri 3 Surakarta, observasi kegiatan pembelajaran di kelas , dan analisis dokumen Unit Kegiatan Belajar Mandiri (UKBM) yang dibuat oleh guru mata pelajaran PPKn.

\section{HASIL PENELITIAN DAN PEMBAHASAN}

Peneliti dalam sub bab ini menganalisis data yang berhasil dikumpulkan di lapangan sesuai dengan rumusan masalah penelitian ini, selanjutnya dikaitkan dengan teori yang ada. Berdasarkan hasil penelitian yang telah dijelaskan di atas, maka dalam penelitian ini disajikan beberapa pembahasan yaitu sebagai berikut:
1. Strategi Guru dalam
Pembelajaran Berpikir Kritis
Peserta Didik Melalui Unit
Kegiatan Belajar Mandiri
Mata Pelajaran Pendidikan
Pancasila 


\section{Kewarganegaraan d i SMA Negeri 3 Surakarta}

Berdasarkan hasil temuan penelitian, strategi guru dalam meningkatkan kemampuan berpikir kritis peserta didik melalui Unit Kegiatan Belajar Mandiri mata pelajaran Pendidikan Pancasila dan Kewarganegaraan di SMA Negeri 3 Surakarta adalah:

\section{a. Guru mempelajari}

komponen pengembangan dan karakteristik Unit Kegiatan Belajar Mandiri (UKBM)

Guru mempelajari komponen pengembangan dan karakteritik UKBM. Komponen pengembangan dan karakteritik UKBM mata pelajaran Pendidikan Pancasila dan Kewarganegaraan sesuai dengan komponen yang terdapat di Naskah Panduan Pengembangan Unit Kegiatan Belajar Mandiri Tahun 2017.

Guru mempelajari komponen pengembangan UKBM menurut Naskah Panduan Pengembangan Unit Kegiatan Belajar Mandiri (UKBM) di SMA dengan langkah sebagai berikut : Menjadikan Buku Teks Pelajaran (BTP) sebagai sumber belajar utama yang dapat diperkaya dengan sumber-sumber yang lebih actual dan relevan lainnya, Menampilkan Kompetensi Inti (KI) dan Kompetensi Dasar (KD) di dalam UKBM mata pelajaran PPKN, Menampilkan tugas dan pengalaman belajar sesuai dengan kompetensi yang akan dicapai serta alat evaluasi diri.
Guru mempelajari komponen karakteristik UKBM menurut Naskah Panduan Pengembangan Unit Kegiatan Belajar Mandiri (UKBM) di SMA dengan langkah sebagai berikut : Membuat UKBM mata pelajaran PPKn yang Berbasis KD, Kelanjutan/pengembangan terhadap penguasaan BTP, Dapat mengukur ketuntasan/pencapaian kompetensi setiap mata pelajaran, Bentuk kegiatan pembelajarannya berpusat pada peserta didik (student active) dengan menggunakan berbagai model dan/atau metode pembelajaran dengan pendekatan saintifik (berbasis proses keilmuan) maupun pendekatan lain yang relevan, Memanfaatan teknologi pembelajaran sesuai dengan konsep dan prinsip Techno Pedagogical Content Knowledge (TPACK), Kegiatan pembelajarannya yang mendidik dan dialogis yang bermuara pada berkembangnya kecakapan hidup Abad 21 atau dikenal dengan 4C (critical thinking, creativity, collaboration, communication) atau berpikir kritis, bertindak kreatif, bekerjasama, dan berkomunikasi, tumbuhnya Higher Order Thinking Skills (HOTS) atau Keterampilan Berpikir Tingkat Tinggi (KeBiTT), serta berkarakter.

Seluruh proses berpikir harus dikembangkan dalam satu kesatuan proses psikologispedagogis secara utuh, Bersifat terapan pada tingkat berpikir analisis (C4), evaluasi (C5), dan kreasi (C6), harus dapat mengembangkan peserta didik 
untuk mengaktualisasikan berbagai potensi yang dimilikinya sebagai pembelajar cepat, normal, dan lambat. Pembelajarannya dirancang secara menarik, dinamis, merangsang, menginspirasi, sekaligus meyakinkan peserta didik bahwa kompetensi yang sedang dipelajari dapat dikuasai dengan mudah, sederhana dan bermakna untuk kehidupannya, dan terakhir penampilan UKBM menarik minat belajar peserta didik.

b. Guru membuat kegiatan pembelajaran dengan menampilkan soal-soal Higher Order Thingking Skills (HOTS) yang menunjang peningkatan kemampuan berpikir kritis peserta didik mata pelajaran PPKn

Guru membuat kegiatan pembelajaran di dalam UKBM mata pelajaran PPKn dengan langkah menampilkan soal-soal Higher Order Thingkng Skills (HOTS) yang bersifat terapan pada tingkat berpikir analisis (C4), evaluasi (C5), dan kreasi (C6) yang membantu meningkatkan kemampuan berpikir kritis peserta didik. Hal ini sesuai dengan Teori Piaget yang menekankan pentingnya kegiatan seorang murid yang aktif dalam menkomstruksi pengetahuan (Paul Suparno, 2012: 143). Oleh karena itu, kegiatan aktif dalam proses belajar itu perlu ditekankan, seorang peserta didik akan lebih mengerti apabila ia dapat menemukan sendiri pengetahuannya. Teori ini jika dihubungkan dengan penelitian yang peneliti angkat adalah bahwa peserta didik terlibat dalam proses pembelajaran dengan mengerjakan soal-soal berkognitif tingkat tinggi yang menuntut peserta didik untuk meningkatkan kemampuan berpikir kritisnya melalui Unit Kegiatan Belajar Mandiri (UKBM) mata pelajaran PPKn.

c. Guru membuat tampilan Unit Kegiatan Belajar Mandiri (UKBM) mata pelajaran PPKn yang menarik

Guru membuat UKBM mata pelajaran PPKn dengan strategi membuat tampilan UKBM mata pelajaran PPKn yang menarik yang akan memancing peserta didik untuk mempelajari dan mengerjakan UKBM mata pelajaran PPKn yang berisi materi dan soal-soal berkognitif tinggi seperti dengan menyertakan contoh gambar ilustrasi sesuai materi, menampilkan banyak warna, dan kegiatan pembelajarannya menuntun peserta didik untuk berpikir kritis. Membuat tampilan UKBM yang menarik sesuai dengan bagian dari karakteristik UKBM yang terdapat dalam Naskah Panduan Pengembangan Unit Kegiatan Belajar Mandiri yang diterbitkan oleh Direktorat Pembinaan sekolah menengah atas Kemendikbud (2017 :3) bahwa penampilan UKBM sebisa mungkin harus menarik minat belajar peserta didik dan juga, UKBM harus memiliki sifat hangat untuk peserta didik hal 
tersebut tercantum di dalam buku panduan pengembangan UKBM yang diterbitkan oleh direktorat pembinaan sekolah menengah atas Kemendikud (2017: 4) hangat yang dimaksud adalah UKBM harus bisa menarik minat peserta didik untuk belajar, membangun rasa penasaran, dan terbuka.

Strategi guru dalam pembelajaran berpikir kritis peserta didik melalui Unit Kegiatan Belajar Mandiri mata pelajaran Pendidikan Pancasila dan Kewarganegaraan di atas sesuai dengan Naskah Panduan Pengembangan Unit Kegiatan Belajar Mandiri Tahun 2017 yang menjelaskan bahwa UKBM sebagai perangkat belajar bagi peserta didik untuk mencapai kompetensi pengetahuan dan keterampilan pada pembelajaran dengan menggunakan Sistem Kredit Semester sekaligus sebagai wahana peserta didik untuk menumbuhkan kecakapan hidup Abad 21 seperti berpikir kritis.

d. Guru merancang kegiatan perencanaan, pelaksanaan, dan evaluasi

Guru merancang kegiatan perencanaan dengan strategi seperti membuat perangkat UKBM dan harus yang berbasis KD sesuai materi PPKn, pengembangan terhadap penguasaan BTP, dan dengan membuat soal dalam UKBM PPKn pun harus berbasis HOTS untuk meningkatkan kemampuan berpikir kritis peserta didik.

Kegiatan pelaksanaannya guru menyesuaikan materi yang akan diajarkan di dalam kelas, peserta didik diberikan UKBM pada pertemuan sebelumnya, jadi apa yang akan dipertanyakan peserta didik sudah direncanakan atau sudah ada gambaran, sehingga guru tinggal memandu dalam arti peserta didik yang aktif, dan guru menerapkan UKBM mata pelajaran PPKn pada kegiatan pembelajaran di kelas sedangkan untuk kegiatan evaluasi guru merancang dengan cara memberi penilaian kepada peserta didik seperti tes dan menilai berdasarkan keaktifan peserta didik pada saat pembelajaran berlangsung. Kegiatan

perencanaan, pelaksanaan, dan evaluasi strategi guru dalam pembelajaran berpikir kritis peserta didik melalui UKBM mata pelajaran dapat dibuat dalam tabel di bawah ini: 
Tabel 4.1 Kegiatan perencanaan, pelaksanaan, dan evaluasi

\begin{tabular}{|c|c|c|}
\hline No & Kegiatan & Ingkah \\
\hline 1. & Perencanaan & $\begin{array}{l}\text { a. Membuat perangkat UKBM mata pelajaran } \\
\text { PPKn berbasis KD. } \\
\text { b. Membuat UKBM mata pelajaran PPKn } \\
\text { sebagai pengembangan terhadap penguasaan } \\
\text { Buku Teks Pelajaran (BTP). Membuat } \\
\text { kegiatan pembelajaran di dalam UKBM mata } \\
\text { pelajaran PPKn yang berbasis HOTS (Higher } \\
\text { Order Thinking Skills). }\end{array}$ \\
\hline 2. & Pelaksanaan & $\begin{array}{l}\text { a. Membuat UKBM mata pelajaran PPKn } \\
\text { dengan menyesuaikan materi yang akan } \\
\text { diajarkan di dalam kelas. } \\
\text { b. Menerapkan UKBM mata pelajaran PPKn } \\
\text { sebagai perangkat pembelajaran mandiri bagi } \\
\text { peserta didik di rumah dan di kelas. }\end{array}$ \\
\hline
\end{tabular}

3. Evaluasi

a. Memberi Penilaian kepada peserta didik melalui soal tes.

b. Memberi Penilaian kepada peserta didik berdasarkan keaktifan peserta didik pada saat kegiatan pembelajaran menggunakan UKBM mata pelajaran PPKn.

Hal demikian sejalan dengan panduan yang terdapat dalam Naskah Panduan Pengembangan Unit Kegiatan Belajar Mandiri bahwa terlebih dahulu guru harus membuat perangkat UKBM dan harus yang berbasis KD, Pelaksanaannya membuat kegiatan pembelajaran yang terdapat dalam UKBM yang menarik, kegiatan pembelajarannya mendidik dan dialogis serta memiliki dampak pengiring berupa proses pembentukan karakter sebagai wujud keterpaduan semua KI dan KD, Higher Order Thinking Skill (HOTS) atau Keterampilan BerpikirTingkat Tinggi (KeBiTT), tumbuhnya kecakapan hidup Abad 21 salah satunya adalah berpikir kritis. Untuk kegiatan evaluasinya dengan menanyakan kembali permasalahan yang diangkat pada bagian pemandu awal guna memastikan bahwa penguasaan konsep mulai dari pemandu awal hingga kegiatan belajar 1, 2, 3 dan seterusnya menjadi bagian dari pola berpikir sistematis peserta didik.

2. Faktor Pendukung dan Faktor Penghambat Guru dalam Pembelajaran Berpikir Kritis 


\section{Peserta Didik Melalui Unit Kegiatan Belajar Mandiri Mata Pelajaran Pendidikan Pancasila dan Kewarganegaraan di SMA Negeri 3 Surakarta}

Guru Pendidikan Pancasila dan Kewarganegaraan dalam pembelajaran berpikir kritis peserta didik melalui Unit Kegiatan Belajar Mandiri mata pelajaran PPKn menemui beberapa faktor pendukung dan beberapa faktor penghambat. Berdasarkan hasil temuan penelitian faktor pendukung dan faktor penghambat guru dalam pembelajaran berpikir kritis peserta didik melalui Unit Kegiatan Belajar Mandiri mata pelajaran PPkn antara lain:

\section{a. Faktor pendukung}

Faktor pendukung guru dalam pembelajaran berpikir kritis peserta didik melalui Unit Kegiatan Belajar Mandiri mata pelajaran PPKn: 1) Fasilitas sarana dari sekolah mendukung: seperti adanya media pembelajaran yang lengkap dan jaringan internet yang membantu peserta didik untuk mendapat informasi tambahan; 2) Adanya respon positif dari peserta didik: Peserta didik menyambut dengan baik terkait adanya UKBM mata pelajaran PPKn: Adanya UKBM mata pelajaran PPKn membantu peserta didik dalam belajar mandiri untuk semakin cepat menguasai materi pelajaran karena peserta didik dituntut berpikir kritis; 3) Kegiatan pembelajaran dalam UKBM mata pelajaran PPKn mengarah pada tumbuhnya HOTS yang mendukung kecakapan berpikir kritis: Bersifat terapan pada tingkat berpikir analisis (C4), evaluasi (C5), dan kreasi (C6) yang membantu meningkatkan kemampuan berpikir kritis peserta didik; dan 4) UKBM mata pelajaran PPKn sebagai strategi pembelajar mandiri yang membantu peserta didik mencapai ketuntasan belajar: Peserta didik memperoleh kesempatan dan mencapai tingkat kemampuan optimal sesuai dengan bakat, minat, dan kemampuan atau ke cepatan belajar dalam hal ini paa khususnya kecepatan belajar yang terdapat dalam mata pelajaran PPKn.

Faktor tersebut berkaitan dengan pendapat Widodo dan Jusmadi (dalam Lestari 2013: 2) bahwa bahan ajar harus memiliki karakteristik user friendly yaitu setiap instruksi dan paparan informasi yang tampil bersifat membantu dan besahabat dengan pemakainya, termasuk kemudahan pemakai dalam merespon dan mengakses sesuai dengan keinginan, oleh karenanya adanya fasilitas sarana dari sekolah yang mendukung dan adanya respon positif dari peserta didik merupakan akibat yang ditimbulkan bahwa UKBM mata pelajaran PPKn memiliki karakteristik user friendly. Lestari (2013: 3) mengungkapkan bahwa sebuah bahan ajar yang baik harus mencakup ; petunjuk belajar, kompetensi yang akan dicapai, informasi pendukung, latihan-latihan, petunjuk kerja dan evaluasi, di dalam UKBM mata pelajaran PPKn yang dibuat oleh guru untuk latihan soalnya dibuat yang berpusat pada peserta didik yang mendorong kemapuan berpikir tingkat tinggi (HOTS) oleh karenanya hal ini sebagai faktor pendukung peserta didik 
memiliki kecakapan hidup Abad 21 salah satunya berpikir kritis dalam mata pelajaran PPKn. UKBM sebagai fasilitator kecepatan belajar peserta didik, bahwa tujuan diterapkannya UKBM adalah untuk memfasilitasi kecepatan belajar peserta didik karena sehubungan dengan diterapkannya SKS (Sistem Kredit Semester) di SMA Negeri 3 Surakarta.

Berdasarkan hasil penelitian, UKBM mata pelajaran PPKn memfasilitasi kecepatan belajar peserta didik sesuai dengan salah satu prinsip dalam penyelenggaraan Sistem Kredit Semester (SKS) yaitu harus memiliki keunggulan. Hal tersebut tercantum dalam peraturan menteri pendidikan kebudayaan (Permendikbud) nomor 158 tahun 2014 keunggulan yang dimaksud adalah memungkinkan peserta didik memperoleh kesempatan dan mencapai tingkat kemampuan optimal sesuai dengan bakat, minat, dan kemampuan atau kecepatan belajar dalam hal ini paa khususnya kecepatan belajar yang terdapat dalam mata pelajaran PPKn.

b. Faktor penghambat

1. Faktor internal

Faktor pennghambat internal dalam pembelajaran berpikir kritis peserta didik melalui Unit Kegiatan Belajar Mandiri mata pelajaran PPKn: (a) Adanya perasaan takut dari diri peserta didik: Perasaan takut dari diri peserta didik dikarenakan mereka takut salah menjawab sehingga mereka cenderung pasif untuk berpikir kritis. Upaya yang sudah dilakukan oleh guru untuk mengatasi faktor penghambat adanya perasaan takut diri peserta didik adalah dengan berusaha memahami karakteristik peserta didik dan membangun hubungan kedekatan dengan peserta didik supaya mereka tidak takut untuk mengemukakakan pemikiran kritisnya; (b) Peserta didik kesulitan dalam menyampaikan pemikirannya karena kurangnya kemampuan berkomunikasi: Peserta didik kesulitan dalam menyampaikan pemikirannya karena kurangnya kemampuan berkomunikasi yang menyebabkan mereka cenderung menerima setiap materi apa saja yang diberikan oleh guru sehingga menyebabkan kemampuan berpikir kritis kurang. Untuk faktor penghambat ini guru masih kesulitan untuk mengatasinya dikarenakan masing-masing peserta didik memiliki karakteristik yang berbedabeda; dan (c) Kurangnya motivasi dalam diri peserta didik dikarenakan kurang berminat pada mata pelajaran Pendidikan Pancasila dan Kewarganegaraan karena banyaknya materi hafalan: Kurangnya motivasi dalam diri peserta didik dikarenakan kurang berminat pada mata pelajaran Pendidikan Pancasila dan Kewarganegaraan karena banyaknya materi hafalan sehingga untuk berpikir kritis dalam mata pelajaran PPKn cenderung sulit. Upaya yang sudah dilakukan oleh guru untuk mengatasi faktor penghambat kurangnya motivasi dalam diri peserta didik adalah dengan memberikan motivasi kepada peserta didik pada saat kegiatan pembelajaran.

2. Faktor Eksternal

Faktor penghambat internal dalam pembelajaran berpikir kritis peserta didik melalui Unit Kegiatan Belajar Mandiri mata pelajaran 
PPKn: (a) Respon teman sekitar yang sering mentertawakan temannya saat peserta didik salah menjawab sehingga peserta didik hanya diam menerima apa saja materi yang disampaikan oleh guru: Respon teman sekitar yang sering mentertawakan peserta didik lain saat salah menjawab sehingga mereka hanya diam menerima apa saja materi yang disampaikan oleh guru. Upaya yang sudah dilakukan oleh guru untuk mengatasi faktor penghambat ini adalah dengan menegur peserta didik lain yang menertawakan temannya ketika salah menjawab pertanyaan dari guru atau pada saat mencoba mengemukakan pemikiran kritisnya; (b) Masalah terbatasnya alokasi waktu: Masalah terbatasnya alokasi waktu sehingga peserta didik sulit untuk meningkatkan kemampuan berpikir kritisnya dikarenakan kurangnya waktu belajar mereka. Masalah terbatasnya alokasi waktu tidak bisa diatasi oleh guru dikarenakan terbatasnya jam pelajaran dan tuntutan materi harus segera diselesaikan sesuai jadwal; (c) Peserta didik yang sudah menyelesaikan UKBM mata pelajaran PPKn harus menunggu peserta didik yang lainnya untuk mendapatkan materi baru yang akan diajarkan oleh guru: Untuk mendapatkan materi baru yang dijelaskan oleh guru peserta didik harus menunggu peserta didik lain dalam pengerjaan UKBM sehingga keadaan seperti ini akan menghambat bagi peserta didik yang memiliki tingkat potensi belajar cepat. Masalah ini juga belum bisa diatasi oleh guru dikarenakan guru tidak bisa memaksakan peserta didik untuk memiliki tingkat potensi belajar cepat seperti temannya; dan (d) Kesulitan mencetak UKBM mata pelajaran PPKnUKBM mata pelajaran PPKn belum dibukukan secara rapi dikarenakan keterbatasan dana yang menyebabkan peserta didik kesulitan untuk merawatnya sehingga mudah tercecer. Masalah ini juga belum bisa diatasi oleh guru dilapangan dikarenakan guru belum memiliki cara atau ide yang pas untuk mengatasi masalah ini.

Faktor penghambat guru dalam berpikir kritis peserta didik melalui Unit Kegiatan Belajar Mandiri (UKBM) mata pelajaran PPKn disebabkan beberapa faktor yang ada pada peserta didik, yang mana dikelompokkan menjadi faktor internal dan faktor eksternal, hal ini sejalan dengan pendapat Miller dalam Karnadi (2009: 109):

a. Faktor internal

1) Faktor bawaan (innate drive);

2) Jenis Kelamin (sex different).

b. Faktor eksternal

1) Pola asuh orang tua (parenting style);

2) Peniruan (modeling);

3) Hiburan (entertainment);

4) Teman sebaya (peer influence);

5) Pendidikan di sekolah (education).

Berdasarkan hasil penelitian yang diperoleh melalui teknik wawancara dan observasi diketahui faktor penghambat guru dalam meningkatkan kemampuan berpikir kritis peserta didik melalui Unit Kegiatan Belajar 
Mandiri (UKBM) mata pelajaran PPKn: a) adanya perasaan takut dari diri peserta didik; b) Peserta didik kesulitan dalam menyampaikan pemikirannya karena kurangnya kemampuan berkomunikasi dan c) kurangnya motivasi dalam diri peserta didik dikarenakan kurang berminat pada mata pelajaran Pendidikan Pancasila dan .Kewarganegaraan karena banyaknya materi hafalan. Faktor tersebut jika dikaitkan dengan pendapat Miller diatas maka faktor yang ditemukan oleh peneliti sesuai dengan faktor bawaan yang disampaikan oleh Miller dikarenakan adanya faktor perasaan takut pada peserta didik memang sudah tertanam dari dalam diri peserta didik sendiri dimana peserta didik tersebut merupakan peserta didik yang pemalu atau penakut dan diam di kelas.

Sementara faktor eksternal yaitu: a) respon teman sekitar yang sering mentertawakan temannya saat peserta didik salah menjawab sehingga peserta didik hanya diam menerima apa saja materi yang disampaikan oleh guru; b) Masalah terbatasnya alokasi waktu; c) peserta didik yang sudah menyelesaikan Unit Kegiatan Belajar Mandiri (UKBM) mata pelajaran PPKn harus menunggu peserta didik yang lainnya untuk mendapatkan materi baru yang akan diajarkan oleh guru; dan d) kesulitan mencetak Unit Kegiatan Belajar Mandiri (UKBM) mata pelajaran PPKn dikarenakan keterbatasan dana jika dikaitkan dengan dalam teori yang dikemukakan oleh
Miller di atas maka dari lima faktor hanya terdapat dua faktor yang sesuai dengan teori yang disampaikan oleh Miller yaitu faktor eksternal yang berasal dari teman sebaya dan faktor pendidikan di sekolah.

Selain itu faktor faktor pendukung dan faktor penghambat guru dalam pembelajaran berpikir kritis peserta didik melalui UKBM tersebut juga disebutkan dalam Penelitian Mochamad Dana (2017) yang menyatakan bahwa faktor pendukung guru dalam menerapkan UKBM adalah UKBM sebagai perangkat belajar bagi peserta didik dalam mencapai kompetensi pengetahuan dan keterampilan pada pembelajaran dan peserta didik telah menyetujui dan menerima pembelajaran menggunakan UKBM, sedangkan faktor penghambat guru dalam menerapkan Unit Kegiatan Belajar Mandiri (UKBM) adalah kesulitan peserta didik menguasai materi pelajaran disebabkan karena faktor motivasi, minat, bentuk pelajaran, dan guru. Faktor tersebut jika dikaitkan dengan pendapat Miller diatas maka sejalan dengan faktor internal bawaan yang disampaikan oleh Miller dikarenakan kurangnya motivasi dalam diri peserta didik. Selain itu, juga sejalan dengan faktor eksternal pendidikan di sekolah.

\section{SIMPULAN DAN SARAN}

\section{A. SIMPULAN}

Berdasarkan data yang telah dikumpulkan di lapangan serta analisis yang telah dilakukan oleh 
peneliti maka dapat ditarik kesimpulan sebagai berikut:

1. Strategi guru dalam pembelajaran berpikir kritis peserta didik melalui Unit Kegiatan Belajar Mandiri mata pelajaran Pendidikan Pancasila dan Kewarganegaraan di SMA Negeri 3 Surakarta dilakukan dengan langkah-langkah strategi sebagai berikut:

a. Guru mempelajari komponen pengembangan dan karakteristik UKBM untuk meningkatkan kemampuan berpikir kritis peserta didik.

b. Guru membuat kegiatan pembelajaran dengan menampilkan soal-soal HOTS yang menunjang peningkatan kemampuan berpikir kritis peserta didik mata pelajaran PPKn.

c. Guru membuat tampilan UKBM mata pelajaran PPKn yang menarik untuk meningkatkan kemampuan berpikir kritis peserta didik.

d. Guru merancang kegiatan perencanaan, pelaksanaan, dan evaluasi untuk meningkatkan kemampuan berpikir kritis peserta didik.

2. Faktor pendukung dan faktor penghambat guru dalam pembelajaran berpikir kritis peserta didik melalui Unit Kegiatan Belajar Mandiri mata pelajaran Pendidikan Pancasila dan Kewarganegaraan di SMA Negeri 3 Surakarta adalah sebagai berikut:

a. Faktor pendukung

1) Fasilitas sarana dari sekolah mendukung yang membantu peserta didik untuk memperoleh informasi tambahan dan menuntun mereka untuk berpikir kritis.

2) Adanya respon positif dari peserta didik karena dengan adanya UKBM mata pelajaran PPKn membantu mereka dalam belajar mandiri untuk semakin cepat menguasai materi pelajaran karena peserta didik dituntut berpikir kritis.

3) Kegiatan pembelajaran dalam UKBM mata pelajaran PPKn mengarah pada tumbuhnya HOTS yang mendukung kecakapan berpikir kritis.

4) UKBM mata pelajaran PPKn sebagai strategi pembelajar mandiri yang membantu peserta didik mencapai ketuntasan belajar.

b. Faktor Penghambat

1) Faktor internal

a) Adanya perasaan takut dari diri peserta didik dikarenakan mereka takut salah menjawab sehingga mereka cenderung pasif untuk berpikir kritis.

b) Peserta didik kesulitan dalam menyampaikan pemikirannya karena kurangnya kemampuan berkomunikasi yang menyebabkan mereka cenderung menerima setiap materi apa saja yang diberikan oleh guru sehingga menyebabkan 
kemampuan berpikir kritis kurang.

c) Kurangnya motivasi dalam diri peserta didik dikarenakan kurang berminat pada mata pelajaran Pendidikan Pancasila dan Kewarganegaraan karena banyaknya materi hafalan sehingga untuk berpikir kritis dalam mata pelajaran PPKn cenderung sulit.

2) Faktor Eksternal

a) Respon teman sekitar yang sering mentertawakan peserta didik lain saat salah menjawab sehingga mereka hanya diam menerima apa saja materi yang disampaikan oleh guru.

b) Masalah terbatasnya alokasi waktu sehingga peserta didik sulit untuk meningkatkan kemampuan berpikir kritisnya dikarenakan kurangnya waktu belajar mereka.

c) Peserta didik yang sudah menyelesaikan UKBM mata pelajaran PPKn harus menunggu peserta didik yang lainnya untuk mendapatkan materi baru yang akan diajarkan oleh guru hal ini akan menghambat bagi peserta didik yang memiliki potensi belajar cepat. d) Kesulitan mencetak UKBM mata pelajaran PPKn dikarenakan keterbatasan dana yang menyebabkan peserta didik kesulitan untuk merawatnya sehingga mudah tercecer.

\section{B. SARAN}

Berdasarkan kesimpulan dan implikasi di atas, maka peneliti dapat mengemukakan saran sebagai berikut:

1. Bagi guru Pendidikan Pancasila dan Kewarganegaraan

a. Guru sebaiknya memaksimalkan strategi yang digunakan dalam pembelajaran berpikir kritis peserta didik dan senantiasa berupaya meminimalisir faktor yang dapat menghambat peserta didik dalam pembelajaran berpikir kritis melalui Unit Kegiatan Belajar Mandiri (UKBM) mata pelajaran Pendidikan Pancasila dan Kewarganegaraan supaya peserta didik dapat berpikir kritis.

b. Guru sebaiknya dapat membangun komunikasi yang dapat menimbulkan kedekatan antara guru dan pesert didik yang membuat peserta didik merasa nyaman sehingga tidak takut berargumen menyampaikan pemikiran kritisnya.

c. Guru sebaiknya memperbaiki cetakan tampilan Unit Kegiatan Belajar Mandiri (UKBM) mata pelajaran Pendidikan Pancasila dan Kewarganegaraan supaya tidak mudah rusak sehingga 
tidak tercecer atau guru bisa membagikan Unit Kegiatan Belajar Mandiri (UKBM) mata pelajaran Pendidikan Pancasila dan Kewarganegaraan dalam bentuk softfile.

2. Bagi peserta didik

a. Peserta didik sebaiknya dapat memotivasi dirinya sendiri untuk berpikir kritis dan berani menyampaikan pemikiran kritisnya dalam mata pelajaran Pendidikan Pancasila dan Kewarganegaraan dengan berusaha menghilangkan perasaan takutnya.

b. Peserta didik sebaiknya dapat menghargai temannya yang mencoba menjawab pertanyaan guru atau mengemukakan gagasannya dengan tidak menertawakan temannya yang mengalami kesalahan dalam menjawab pertanyaan guru.
3. Bagi Peneliti lain

1. Peneliti lain hendaknya meneliti terkait apakah Unit Kegiatan Belajar Mandiri (UKBM) mata pelajaran Pendidikan Pancasila dan Kewarganegaraan mampu meningkatkan kemampuan berpikir kritis peserta didik. Hal tersebut dikarenakan keterbatasan peneliti yang hanya meneliti terkait strategi guru dalam pembelajaran berpikir kritis melalui Unit Kegiatan Belajar Mandiri (UKBM) mata pelajaran Pendidikan Pancasila dan Kewarganegaraan, sehingga masih perlu digali informasi yang lebih mendalam lagi untuk diteliti.

\section{DAFTAR PUSTAKA}

Hartatik, Sri. (2018). Unit Kegiatan Belajar Mandiri Mata Pelajaran Pendidikan Pancasila dan Kewarganegaraan. Surakarta: SMA Negeri 3 Surakarta.

Kemendikbud. (2017). Buku Guru Pendidikan Pancasila dan Kewarganegaraan. Jakarta: Kementrian Pendidikan dan Kebudayaan

Lestari, Ika.(2013). Pengembangan Bahan Ajar Berbasis Kompetensi: Sesuai dengan Kurikulum Tingkat Satuan Pendidikan. Jakarta: Akademia Permata.

Mulyasa,E. (2005). Kurikulum Berbasis Kompetensi: Konsep, Karakteristik, dan Impementasi. Bandung: PT Remaja Rosdakarya.

Piaget,Jean. (1950). The Psychology of Intelligence. London: Taylor\&Francis eLibrary.

Puskurbuk. (2012). Penguatan Kurikulum Mata Pelajaran Pendidikan Pancasila dan Kewarganegaraan. Jakarta: Kementrian Pendidikan dan Kebudayaan, Badan Penelitian dan Pengembangan, Pusat Kurikulum dan Perbukuan.

Sugiyono. (2011). Metode Penelitian Pendidikan (Pendekatan Kuantitatif, Kualitatif, dan $R \& D)$ ). Bandung: Alfabeta. 
107 Novita Taya Sara, Rusnaini, Winarno: strategi guru dalam pembelajaran ...

Suparno,Paul. (2012). Teori Perkembangan Kognitif Jean Piaget. Yogyakarta: Kanisius.

Winarno. (2013). Pembelajaran Pendidikan Kewarganegaraan. Isi, Strategi, dan Penilaian . Jakarta: Bumi Aksara.

\section{Jurnal}

Dana, Mochamad. (2017). Penggunaan Unit Kegiatan Belajar Mandiri Oleh Guru Dalam Pembelajaran Bahasa Indonesia di Kelas X MIPA 2 SMA Negeri Bali Mandara. Bali. Jurnal Jurusan Pendidikan Bahasa dan Sastra Indonesia Vol.7. No.2. 2017.

Rusnaini. (2018). Pendidikan Kewarganegaraan dan Wawasan Kebangsaan Menuju Visi Indonesia 2025. Surakarta. Diperoleh 21 Januari 2018 dari https://civitas.uns.ac.id/rusnaini/wpcontent/uploads/sites/607/2018/08/PENDIDIK AN-KEWARGANEGARAAN-DAN-WAWASAN-KEBANGSAAN-MENUJUVISI-INDONESIA-2025.pdf

\section{Skripsi, Tesis, dan Disertasi}

Istikomah, Nurul. (2018). Peningkatan Kemampuan Berpikir Kritis Melalui Model Kooperatif Tipe Think Pair Share. Surabaya: Universitas Negeri Sunan Ampel Surabaya.

Ma'rifah, Nurul. (2014). Peningkatan Kemampuan Berpikir Kritis Siswa Melalui Model Cooperative Tipe Think Pair Share Dalam Pembelajaran PKn . Yogyakarta : Universitas Negeri Yogyakarta.

Pratini, Tri. (2015). "Upaya Meningkatkan Kemampuan Berpikir Kritis Dan Kerjasama Siswa Melalui Penerapan Metode Pembelajaran Problem Solving Pada Mata Pelajaran PKn Kelas VII-B SMPN2 LABUAPI". Mataram : Universitas Mataram.

\section{Referensi Undang-Undang :}

Peraturan Menteri Pendidikan dan Kebudayaan Nomor 59 tahun 2014 tentang Kurikulum 2013 SMA

Peraturan Menteri Pendidikan Kebudayaan Nomor 158 Tahun 2014 Tentang Penyelenggaraan Sistem Kredit Semester.

Undang-Undang Nomor 20 tahun 2003 tentang Sistem Pendidikan Nasional.

Yusuf, Munawir. 1998. Pendidikan Tuna Netra Dewasa dan Pembinaan Karier, Jakarta:

Depdikbud. 